\title{
Luzy bezpieczeństwa pomiędzy skrajnią kinematyczną i skrajnią budowli dla pojazdów tramwajowych (1)
}

\begin{abstract}
Artykut jest poświęcony studium luzów bezpieczeństwa występujacych pomiędzy zarysem odniesienia skrajni kinematycznej oraz zarysem odniesienia skrajni budowli. Wielkość luzów bezpieczeństwa jest przyjmowana indywidualnie $w$ zależności od uznania miejskich przedsiębiorstw komunikacyjnych $w$ oparciu o ich doświadczenia eksploatacyjne. Artykut sktada się z dwóch części. Część pierwsza (1) obejmuje wprowadzenie, kinematyczne zapotrzebowanie przestrzeni oraz wyznaczenie tego zapotrzebowania.

Artykut powstat w ramach projektu badawczego nr N 509 03531/2367, finansowanego przez

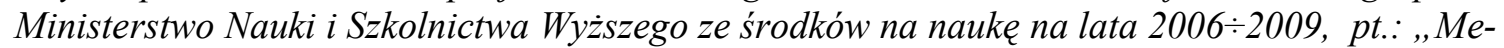
todyka wyznaczania kinematycznego zapotrzebowania przestrzeni oraz luzów bezpieczeństwa dla pojazdów tramwajowych, celem ustalenia optymalnego zarysu pojazdu”.
\end{abstract}

\section{Wprowadzenie}

Pomiędzy zarysem skrajni kinematycznej pojazdu tramwajowego oraz zarysem skrajni budowli występują odległości, które są nazywane luzami bezpieczeństwa (ang. ,individual margins” albo „margin specific in order to take into account special situations”, niem. „Sicherheitsabstände”). Luzy bezpieczeństwa jako pojęcie nie jest zdefiniowane w przepisach krajowych dotyczących projektowania i utrzymania torów tramwajowych [19], czy też w normach określających skrajnię kinematyczną pojazdu tramwajowego PN-K-92008:1998 [12] i normie PN-K92008/Ap1:1998 [13] oraz w normie określającej skrajnię budowli PN-K-92009:1998 [14]. Luzy bezpieczeństwa są zdefiniowane jako pojęcie $\mathrm{w}$ przepisach niemieckich BOStrab [18] i są określane jako odległość pomiędzy kinematycznym zapotrzebowaniem przestrzeni oraz zarysem odniesienia skrajni budowli. Podobna sytuacja pod względem formalnoprawnym występuje w krajowych przepisach kolejowych, gdzie luzy bezpieczeństwa nie są zdefiniowane w normie PN-70/K-02056 [15], określającej skrajnie statyczne pojazdu kolejowego oraz w normie PN69/K-02057 [16] określającej skrajnie budowli jak również wybrane parametry dodatkowej przestrzeni przy budowie nowych normalnotorowych linii PKP lub przy gruntownej przebudowie linii już istniejących oraz przy wznoszeniu budowli i urządzeń na liniach już istniejących. Luzy bezpieczeństwa są natomiast zdefiniowane $\mathrm{w}$ międzynarodowych przepisach: $\mathrm{w}$ karcie UIC 505-1 [9], w karcie UIC 505-4 [10] oraz w karcie UIC 505-5 [11].

Luzy bezpieczeństwa dla pojazdów tramwajowych wynikają $\mathrm{z}$ doświadczeń poszczególnych przedsiębiorstw komunikacyjnych i są przez nie indywidualnie przyjmowane [1,2 i 8]. Analogiczny sposób postępowania jest przyjęty przez poszczególne zarządy kolejowe i uznany przez Międzynarodowy Związek Kolejowy (UIC). Luzy bezpieczeństwa można najprościej zdefiniować jako odległość pomiędzy kinematycznym zapotrzebowaniem przestrzeni dla pojazdu tramwajowego (ang. „rolling stock kinematic gauge”, niem. „Lichtraumbedarf”) oraz zarysem odniesienia skrajni budowli ( ang. ,lineseide structure installation gauge”, niem. „Umgrenzung des lichten Raumes” lub „Lichtramumgrenzung”).

Zarys kinematycznego zapotrzebowania przestrzeni przez pojazd definiuje się jako przestrzeń dla pojazdu przy uwzględnieniu ruchów wzdłużnych i poprzecznych, jak również wszystkich tolerancji i zużyć. Jeśli miejskie przedsiębiorstwo przewozowe lub zarząd kolejowy przyjmie luz bezpieczeństwa równy zero, to wówczas zarys kinematycznego zapotrzebowania przestrzeni pokryje się z zarysem odniesienia skrajni budowli. Przyjęcie zerowej wartości luzu bezpieczeństwa może mieć miejsce o ile prace kontrolne i konserwacyjno-naprawcze odbywały się na tyle często, że gwarantują odtworzenie stanu wyjściowego infrastruktury. Zarys skrajni budowli wynika więc z kinematycznego zapotrzebowania przestrzeni powiększonego o luz bezpieczeństwa.

Luzy bezpieczeństwa na tle zarysu kinematycznego zapotrzebowania przestrzeni dla pojazdu tramwajowego oraz zarysu skrajni budowli sa przedstawione na rys. 1 .

$\mathrm{W}$ metodyce przedstawionej w przepisach niemieckich BOStrab [18] kinematyczne zapotrzebowanie przestrzeni dla pojazdu tramwajowego jest całkowitym zapotrzebowaniem przestrzeni, które może określić konstruktor w oparciu o dokładną wiedzę w zakresie budowy pojazdu oraz infrastruktury tramwajowej. 


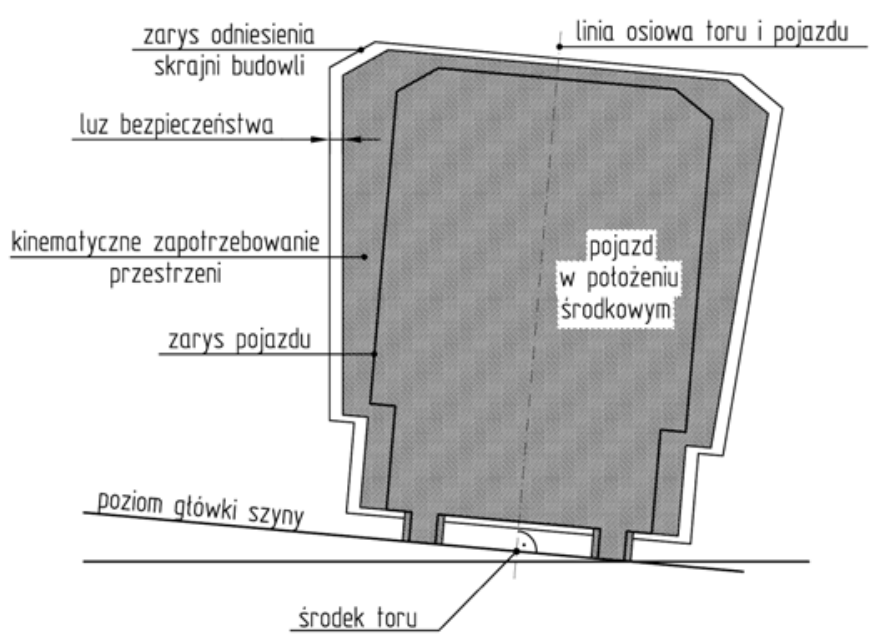

Rys.1. Luzy bezpieczeństwa jako odległość pomiędzy kinematycznym zapotrzebowaniem przestrzeni a zarysem odniesienia skrajni budowli wg przepisów BOStrab [18]

W metodyce przedstawionej w polskich przepisach dla pojazdów tramwajowych oraz ogólnej metodyce dla pojazdów kolejowych konstruktor nie jest zobowiązany do wyznaczania kinematycznego zapotrzebowania przestrzeni przez pojazd. Wynika to z podziału kompetencji za bezpieczną eksploatację pomiędzy konstruktora i służby budowlane.

Różnica w podejściu obydwu metodyk wynika z następujących czynników:

- infrastrukturę tramwajową jest łatwiej skodyfikować i skontrolować w przeciwieństwie do obszernej infrastruktury kolejowej, obejmującej nie tylko sieć krajową ale i zagraniczną ( tabor kolejowy musi być przystosowany do ruchu międzynarodowego)

- odmiennej struktury organizacyjnej przedsiębiorstw kolejowych oraz tramwajowych (miejskie przedsiębiorstwo przewozowe odpowiada również za utrzymanie infrastruktury).

Opracowanie metodyki wyznaczania dopuszczalnego zarysu pojazdu tramwajowego wg PN-K-92008:1998 [12] odbyło się w oparciu o metodykę opracowaną w kolejnictwie.

Dla porównania luzy bezpieczeństwa na tle zarysu kinematycznego zapotrzebowania przestrzeni dla pojazdu kolejowego oraz zarysu skrajni budowli przed-

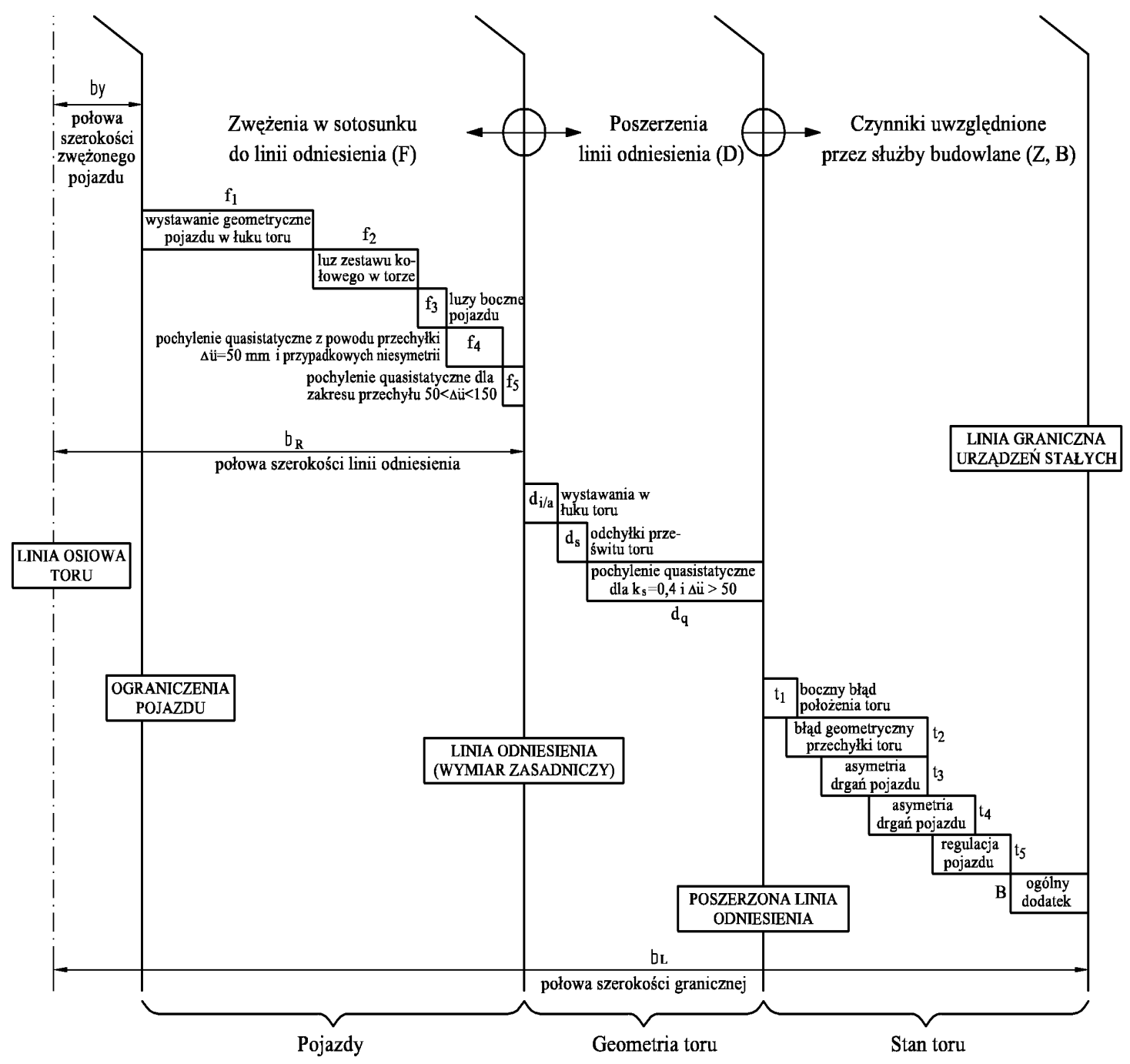

Rys.2. Luzy bezpieczeństwa na tle zarysu kinematycznego zapotrzebowania przestrzeni dla pojazdu kolejowego oraz na tle zarysu skrajni budowli wg [6] 
Kinematyczne zapotrzebowanie przestrzeni dla pojazdu kolejowego o szerokości „2by ” na rys.2 przedstawia poszerzona linia zarysu odniesienia (D), odległa od kinematycznej o przesunięcia wynikające $\mathrm{z}$ geometrii toru.

\section{Kinematyczne zapotrzebowanie przestrzeni dla pojazdu tramwajowego a luzy bezpieczeństwa}

W przypadku pojazdów kolejowych luzybezpieczeństwa posiadają inne znaczenie niż w przypadku pojazdów tramwajowych, choć w niektórych przypadkach można doszukać się analogii. W przypadku tych pierwszych przez luzy bezpieczeństwa rozumie się odległości, które obejmują czynniki działające na pojazd oraz tor w sposób przypadkowy ( wiatr boczny działający na boczną stronę pojazdu, drgania pojazdu i toru, przemieszczenie ladunku podczas jazdy itp.) [1,2,6,8 i 9$]$.

W przypadku pojazdów tramwajowych przy określaniu kinematycznego zapotrzebowania przestrzeni uwzględnia się wszystkie czynniki, które mogą wystapić podczas eksploatacji czyli "nieprzypadkowe” (dodawane do siebie algebraicznie) oraz ,przypadkowe" (dodawane do siebie geometrycznie). W przypadku pojazdów kolejowych kinematyczne zapotrzebowanie przestrzeni określa się przez algebraiczną sumę połowy szerokości pojazdu, wystawań geometrycznych „D” oraz przesunięć poprzecznych „Q”. Zgodnie z przepisami BOStrab [18] jeśli kinematyczne zapotrzebowanie przestrzeni dla danego pojazdu tramwajowego zostało ustalone w oparciu o wszystkie znane czynniki oraz dopuszczalne stany eksploatacyjne (zwłaszcza przy przyjmowaniu przemieszczeń dynamicznych pojazdu, które nie zostaną przekroczone podczas eksploatacji komercyjnej), to wówczas można zrezygnować z uwzględniania luzów bezpieczeństwa. Rezygnacja $\mathrm{z}$ uwzględnienia luzów bezpieczeństwa opiera się na założeniu, że podczas eksploatacji pojazdów tramwajowych będzie dokonywana regularna kontrola pojazdu i urządzeń stałych wraz z ewentualnymi pracami konserwacyjno-naprawczymi $\mathrm{z}$ taka częstotliwością, która odpowiadałaby postępującym procesom zużyciowym, występującym w pojeździє oraz w torze.

Kinematyczne zapotrzebowanie przestrzeni dla pojazdu wyznacza się w dwóch kierunkach: poprzecznym ( niem. "seitlicher Lichtraumbedarf") oraz pionowym ( niem. „vertikaler Lichtraumbedarf”). Kinematycznє zapotrzebowania przestrzeni $\mathrm{w}$ kierunku poprzecznym i pionowym wynika z przemieszczeń rozpatrywanyck przekrojów pojazdu w kierunku poprzecznym ( niem. „Querverschiebung”) oraz w pionowym ( niem. „Vertikalverschiebung"). Jeśli obliczenia kinematycznegc zapotrzebowania przestrzeni w kierunku poprzecznym określonego punktu pojazdu odbywają się w oparciu c nieznane tolerancje konstrukcji pojazdu, usprężynowania i tolerancje budowy oraz własności sprężyste to- ru, wówczas należy przeprowadzić obliczenia szacunkowe (niem. „Überschlagsrechnung”), które oprócz wystawania geometrycznego w łuku toru ( niem. „bogengeometrische Ausragung")- jako wynikającego z bocznego przesunięcia punktu pojazdu w stosunku do osi toru, spowodowanego wyłącznie geometrią łuku toru uwzględniają następujące wielkości:

- maksymalny luz zestawu kołowego w torze ( niem. „maximales Spurspiel”)

- maksymalne przesunięcie toru ( niem. „maximale Querverschiebung")

- maksymalną odchyłkę wzajemnej wysokości szyn bez uwzględnienia wpływu przemieszczenia środka masy $y_{H S}^{*}$ ( niem. ,maximale $\mathrm{Ab}$ weichung der gegenseitigen Höhenlage der Schienen ohne Berücksichtigung des Einflusses der Schwerpunktverlagerung").

W takim przypadku dla pojazdu wykazującego przeciętny komfort jazdy i przy uwzględnieniu normalnego stanu utrzymania i konserwacji pojazdu oraz toru do ustalonego kinematycznego zapotrzebowania przestrzeni należy dodać luz bezpieczeństwa $\mathbf{y}_{\mathbf{S}} \mathrm{w}$ zależności od wysokości badanego punktu pojazdu, o liniowym przebiegu, wynoszący przynajmniej $60 \mathrm{~mm}$ w rejonie podłogi oraz $120 \mathrm{~mm}$ w rejonie dachu. Jak widać $\mathrm{z}$ powyższego, luz bezpieczeństwa jest czynnikiem zryczałtowanym pod względem wartości ( niem. „Pauschalwert”), a jego wartość podana alternatywnie jest uzależniona od usytuowania rozpatrywanego punktu pojazdu.

Dla obliczenia kinematycznego zapotrzebowania przestrzeni w kierunku pionowym określonego punktu pojazdu w odległości b od linii osiowej pojazdu uwzględnia się następujące wielkości:

- pionowe wystawanie geometryczne wynikające z zagłębienia wypukłego ( niem. ,vertikale geometrische Ausragung bei Kuppen") lub wklęsłego ( niem. ,vertikale geometrische Ausragung bei Wannnen") przedstawione odpowiednio na rys. 3 i rys. 4

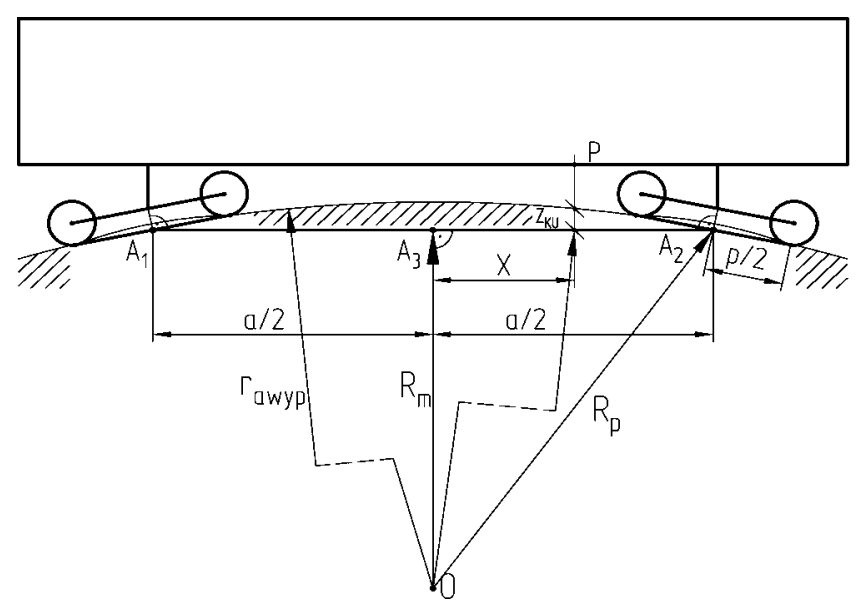

Rys.3. Wystawanie geometryczne w kierunku pionowym wynikające z zagłębienia wypukłego 
- pionowe przemieszczenie wynikające z czynników nieprzypadkowych

- maksymalne przemieszczenia wynikające $\mathrm{z}$ czynników przypadkowych.

Litery podane na rys.3 oznaczają:

a- baza pojazdu tramwajowego ( odległość pomiędzyumownymi środkami wózków)

x - odległość rozpatrywanego punktu pojazdu od punktu oparcia pudła lub umownego środka wózka

p - baza wózka (odległość pomiędzy zestawami kołowymi)

$\mathrm{Z}_{\mathrm{KU}}$ - geometryczne wystawanie pojazdu w kierunku pionowym, wynikające $\mathrm{z}$ wjazdu na zagłębienie wypukłe

$\mathrm{r}_{\text {awyp }}$ - promień zaokraglenia wypukłego odcinka toru

$\mathrm{P}$ - $\quad$ rozpatrywany punkt zarysu pojazdu

O - punkt zaczepienia promienia krzywizny łuku toru $\mathrm{r}_{\text {awyp }} \mathrm{W}$ kierunku pionowym

$\mathrm{R}_{\mathrm{m}}$ - odległość punktu $\mathrm{O}$ od punktu $\mathrm{A}_{3}$ ( środek cięciwy $\mathrm{A}_{1} \mathrm{~A}_{2}$ )

$\mathrm{R}_{\mathrm{P}}$ - odległość punktu $\mathrm{O}$ do punktu $\mathrm{A}_{2}$.

Wielkość $\mathrm{Z}_{\mathrm{KU}}$ można wyznaczyć ze wzoru:

$$
z_{K U}=r_{a w y p}-\sqrt{r_{a w y p}^{2}-\frac{a^{2}}{4}-\frac{p^{2}}{4}+x^{2}}
$$

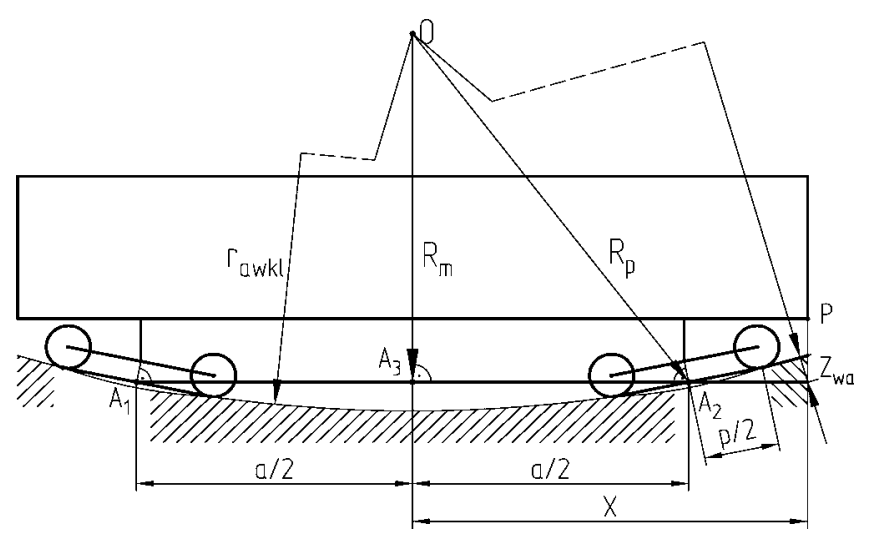

Rys.4. Wystawanie geometryczne w kierunku pionowym wynikające $\mathrm{z}$ zagłębienia wklęsłego

Litery podane na rys. 4 oznaczają:

$\mathrm{Z}_{\mathrm{wa}}$ - geometryczne wystawanie pojazdu w kierunku pionowym, wynikające $\mathrm{z}$ wjazdu na zagłębienie wklęsłe

$\mathrm{r}_{\text {awkl- }}$ promień zaokrąglenia wklęsłego odcinka toru.

Pozostałe litery jak na rys.3.

Wielkość $\mathrm{z}_{\mathrm{wa}}$ można wyznaczyć ze wzoru:

$$
z_{w a}=\sqrt{r_{a w k l}^{2}-\frac{a^{2}}{4}-\frac{p^{2}}{4}+x^{2}}-r_{a w k l}
$$

3. Wyznaczanie kinematycznego zapotrzebowania przestrzeni dla pojazdów tramwajowych bez i z uwzględnieniem luzów bezpieczeństwa

3.1. Wyznaczenie kinematycznego zapotrzebowania przestrzeni dla pojazdów tramwajowych bez uwzględnienia luzów bezpieczeństwa

Kinematyczne zapotrzebowanie przestrzeni dla pojazdów tramwajowych $\mathbf{w}$ kierunku poprzecznym bez uwzględnienia luzów bezpieczeństwa wg wytycznych BOStrab [18] dla poszczególnych przypadków wyznacza się z ogólnego wzoru:

$y=y_{n z 1}+y_{n z 2}+\ldots \ldots \ldots y_{n z i}+\sqrt{y_{z 1}^{2}+y_{z 2}^{2}+\ldots \ldots y_{z j}^{2}}$

gdzie:

$\mathrm{y}_{\mathrm{nz} 1}, \mathrm{y}_{\mathrm{nz} 2 \ldots . . .} \mathrm{y}_{\mathrm{nzi}}$-czynniki działające nieprzypadkowo $\mathrm{w}$ kierunku poprzecznym

$\mathrm{y}_{\mathrm{z} 1}, \mathrm{y}_{\mathrm{z} 2} \ldots \ldots . \mathrm{y}_{\mathrm{zj}}-$ czynniki działające przypadkowo $\mathrm{w}$ kierunku poprzecznym.

Kinematyczne zapotrzebowanie przestrzeni wyznacza się w oparciu o najbardziej niekorzystne ustawienia pojazdu szynowego w torze [3,4,7 i 17].

Czynniki nieprzypadkowe $y_{n z i}$ oraz czynniki przypadkowe $y_{z i}$ są zdefiniowane $\mathrm{w}$ tabeli $7 \mathrm{w}$ opracowaniu [5].

Kinematyczne zapotrzebowanie przestrzeni dla pojazdów tramwajowych w kierunku pionowym bez uwzględniania luzów bezpieczeństwa wg wytycznych BOStrab [18] wyznacza się z ogólnego wzoru:

$z=z_{n z 1}+z_{n z 2}+\ldots \ldots . . . z_{n z i}+\sqrt{z_{z 1}^{2}+z_{z 2}^{2}+\ldots . . z_{z j}^{2}}$

Czynniki nieprzypadkowe $z_{n z i}$ oraz czynniki przypadkowe $z_{z i}$ sa zdefiniowane w przepisach BOStrab [18]. Wyznaczanie czynników nieprzypadkowych poprzez dodawanie geometryczne opiera się na założeniu, że spełniają one zasady normalnego rozkładu częstości zdarzeń ( rozkładu Gaussa).

\subsection{Wyznaczenie kinematycznego zapotrzebowania przestrzeni dla pojazdów tramwajowych $z$ uwzględnieniem luzów bezpieczeństwa}

Kinematyczne zapotrzebowanie przestrzeni $\mathrm{w}$ kierunku poprzecznym dla pojazdów tramwajowych z uwzględnieniem luzów bezpieczeństwa obejmuje trzy zasadnicze przypadki:

- pojazd znajdujący się na trasie jednotorowej

- mijanie się pojazdów tramwajowych na dwóch sąsiadujących torach prostych

- mijanie się pojazdów tramwajowych na dwóch sąsiadujących łukach toru. 
W związku z tym dla jednotorowej trasy kinematyczne zapotrzebowanie przestrzeni wynosi odpowiednio:

gdzie:

$$
y_{P}=b_{a, i}+y_{S S}+\sqrt{y_{G V}^{2}+y_{H S}^{* 2}}+y_{S}
$$

$\mathrm{b}_{\mathrm{a}}$ - odległość punktu P pojazdu od środka toru w wyniku geometrycznego wystawania $\mathrm{w}$ kierunku zewnętrznym łuku toru włącznie z połową szerokości pojazdu

$\mathrm{b}_{\mathrm{i}^{-}}$odległość punktu $\mathrm{P}$ pojazdu od środka toru $\mathrm{w}$ wyniku geometrycznego wystawania $\mathrm{w}$ kierunku wewnętrznym łuku toru włącznie z połową szerokości pojazdu

$\mathrm{y}_{s^{-}}$przesunięcie punktu pojazdu $\mathrm{z}$ powodu luzu zestawu kołowego w torze

$\mathrm{y}_{\mathrm{GV}}$ przesunięcie poprzeczne toru

$y_{H S}^{*}$ - przemieszczenie poprzeczne wynikające ze wzajemnej różnicy wysokości szyn ( zakres odkształceń trwałych)

$\mathrm{y}_{\mathrm{s}}$ - luz bezpieczeństwa w kierunku poprzecznym.

W przypadku mijania się dwóch pojazdów tramwajowych znajdujących się na dwóch sąsiadujących torach prostych kinematyczne zapotrzebowanie przestrzeni, będące bazą do odległości pomiędzy torami, wynosi odpowiednio:

$$
y_{d p}=2\left(b_{a}+y_{S S}\right)+\sqrt{y_{G V}^{2}+2 y_{H S}^{* 2}}+2 y_{S}
$$

W przypadku mijania się dwóch pojazdów tramwajowych znajdujących się na dwóch sąsiadujących lukach toru kinematyczne zapotrzebowanie przestrzeni, będące bazą do odległości pomiędzy torami, wynosi odpowiednio:

$$
y_{d E}=b_{a a}+b_{i b}+y_{S S b}+\sqrt{y_{G V b}^{2}+y_{H S a}^{* 2}+y_{H S b}^{* 2}}+2 y_{S}
$$

gdzie:

indeks a-dla pojazdu na zewnętrznym łuku toru indeks b-dla pojazdu na wewnętrznym łuku toru.

W przypadku zapotrzebowania kinematycznego w kierunku pionowym zaleca się dokładne wykonanie obliczeń wg wzoru (4) zwłaszcza dla punktów krytycznych znajdujących się w rejonie podłogi, stopnia wejściowego oraz dachu. Przyjęcie zaproponowanych luzów bezpieczeństwa analogicznie jak dla przemieszczeń w kierunku poprzecznym może okazać się nie wystarczające.

Przedstawiona metodyka wyznaczania kinematycznego zapotrzebowania przestrzeni jest zbliżona do nowoczesnego podejścia dla pojazdów kolejowych przedstawionego $\mathrm{w}[2]$.

\section{Literatura}

[1] Gasowski W., Sobaś M.: Nowoczesna skrajnia pojazdów kolejowych. Instytut Pojazdów Szynowych , TABOR". Poznań 2005.
[2] Gasowski W., Sobaś M.: Wyznaczanie dopuszczalnego zarysu pojazdu w oparciu skrajnie pojazdów szynowych i budowli. Pojazdy Szynowe Nr 3/2007.

[3] Krugmann H.L.: Lauf der Schienenfahrzeuge im Gleis. Eine Einführung. R. Oldenbourg Verlag GmbH. München Wien 1982.

[4] Sobaś M.: Skrajnia kinematyczna i budowli pojazdów tramwajowych. Pojazdy Szynowe Nr 3/2007.

[5] Sobaś M.: Analiza przemieszczeń geometrycznych $i$ kinematycznych krajowych pojazdów tramwajowych na torze prostym oraz na tuku o minimalnym promieniu. Pojazdy Szynowe Nr 4/2007.

[6] Stier G.: Die kinematische Fahrzeug- und Lichtraum-Geometrie. Systematik und Auswirkungen im Bereich der deutschen Eisenbahnen auf der Grundlage der geänderten Eisenbahn-Bau- und BetriebsOrdnungen bzw. Verordnungen. ZEV+DET Nr.7 Glassers Annalen 07/1992.

[7] Pasemann B., Stüwig M., Theile F.: Beitrag zur Einschränkungsberechnung für Gelenkzüge. ZEV $+D E T$ Glasers Annalen 122. Nr. 4.

[8] Tatara F., Sobaś J.: Analiza geometryczno-statyczna biegu pojazdów szynowych w tukach. Wydawnictwo Politechniki Poznańskiej.04.1967. Nr 191.

[9] Karta UIC 505-1: Pojazdy kolejowe. Skrajnia pojazdów. 10-te wydanie z 05.2006.

[10] Karta UIC 505-4: Wplyw zastosowania skrajni kinematycznych, określonych w karcie UIC 505 na rozmieszczenie budowli $w$ stosunku do torów $i$ na tory między sobq. Wydanie 3 z dnia 01.01.1977 ze zmianq $z$ dnia 01.01.1988.

[11] Karta UIC 505-5: Wspólne warunki podstawowe dla kart 505-1 i 505-4. Komentarz o przygotowaniu tych kart $i$ przepisy ich dotyczace. 2-gie wydanie $z$ 1.01.1977z aktualna zmiana z 1.01.1993.

[12] Norma PN-K-92008:1998: Komunikacja miejska. Skrajnia kinematyczna wagonów tramwajowych.

[13] Norma PN-K-92008/Ap1:1998: Komunikacja miejska. Skrajnia kinematyczna wagonów tramwajowych.

[14] Norma PN-K-92009:1998: Komunikacja miejska. Skrajnia budowli. Wymagania.

[15] PN-70/K-02056: Tabor kolejowy normalnotorowy. Skrajnie statyczne.

[16] PN-69/K-02057: Koleje normalnotorowe. Skrajnie budowli.

[17] Raport ERRI B 176/DT 278: Wplyw przemieszczenia poprzecznego belki bujakowej na profile pojazdów. ( ang.: „Influence of lateral swing bolster play on vehicle profiles"). Utrecht, maj 1993.

[18] Tymczasowe wytyczne dla określenia zapotrzebowania przestrzeni dla kolei miejskich wg zarzqdzenia dotyczqcego budowy i eksploatacji tramwajów (niem. ,Vorläufige Richtlinien für die Bemessung des lichten Raumes nach der Verordnung über den Bau und Betrieb der Straßenbahnen( BOStrab-LichtraumRichtlinien")) .12. 1996.

[19] Wytyczne techniczne projektowania, budowy i utrzymania torów tramwajowych. Ministerstwo Administracji, Gospodarki Terenowej $i$ Ochrony Środowiska. Departament Komunikacji Miejskiej $i$ Dróg. Warszawa 1983. 


\title{
Luzy bezpieczeństwa pomiędzy skrajnią kinematyczną i skrajnią budowli dla pojazdów tramwajowych (2)
}

\begin{abstract}
Artykut jest poświęcony studium luzów bezpieczeństwa wystęujacych pomiędzy zarysem odniesienia skrajni kinematycznej oraz zarysem odniesienia skrajni budowli. W części drugiej (2) przedstawiono przykład obliczeniowy dla kinematycznego zapotrzebowania przestrzeni z i bez uwzględnienia luzów bezpieczeństwa oraz omówienie i wnioski.

Artykut powstat w ramach projektu badawczego $n r N 509$ 03531/2367, finansowanego przez Ministerstwo Nauki i Szkolnictwa Wyższego ze środków na naukę na lata 2006-2009, pt.:, Metodyka wyznaczania kinematycznego zapotrzebowania przestrzeni oraz luzów bezpieczeństwa dla pojazdów tramwajowych, celem ustalenia optymalnego zarysu pojazdu".
\end{abstract}

\section{Przykład obliczeniowy dla tramwaju $z$ wysoką podłogą w stosunku do poziomu główki szyny ( niem. „Hochflurstrassenbahnfahrzeug”)}

\subsection{Parametry pojazdu}

Kinematyczne zapotrzebowanie przestrzeni w kierunku poprzecznym dla pojazdu tramwajowego $\mathrm{z}$ wysoko położoną podłogą $(1000 \mathrm{~mm}$ w stanie próżnym oraz $943 \mathrm{~mm}$ w stanie ładownym od poziomu główki szyny) przedstawionego na rys.5, wyznaczono dla trzech skrajnych położeń pojazdu w torze, przedstawionych w zależności od rozpatrywanego przypadku odpowiednio na rys. 6,7 i 8.
Wybrany pojazd tramwajowy ma charakter reprezentatywny dla już użytkowanego taboru tramwajowego $\mathrm{w}$ miejskich przedsiębiorstwach przewozowych Europy i odpowiada większości wyprodukowanych pojazdów również dla szybkiej kolei miejskiej ( niem. „Stadtbahnfahrzeuge”) oraz zespołów trakcyjnych metra ( niem. „U-Bahnwagen”). $\mathrm{Na}$ tej podstawie można wyciagać wnioski co do uniwersalności zastosowania metody podanej w [1] dla innych pojazdów oraz przyjęcia jej do określenia dopuszczalnego zarysu pojazdu tramwajowego w warunkach polskich przedsiębiorstw przewozowych.

a)
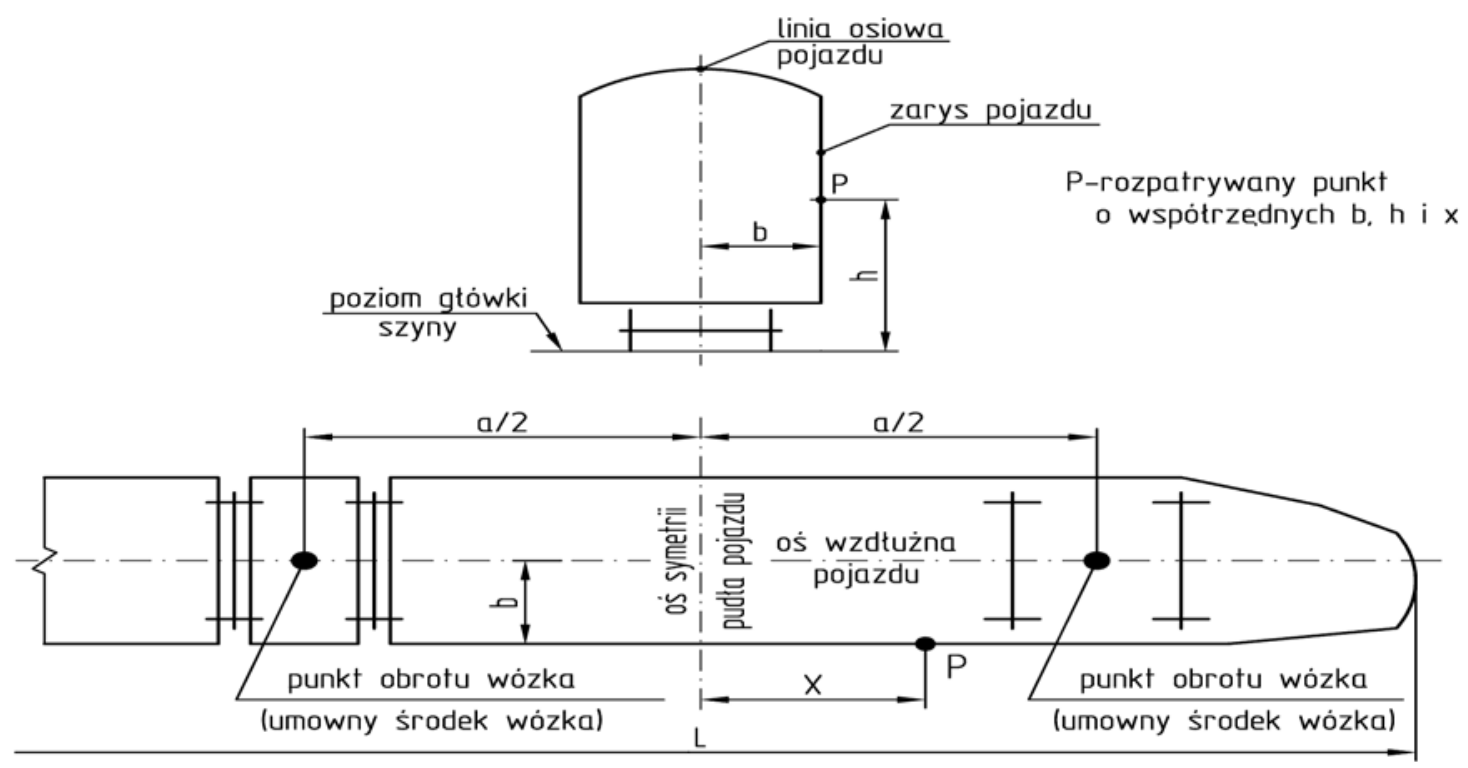

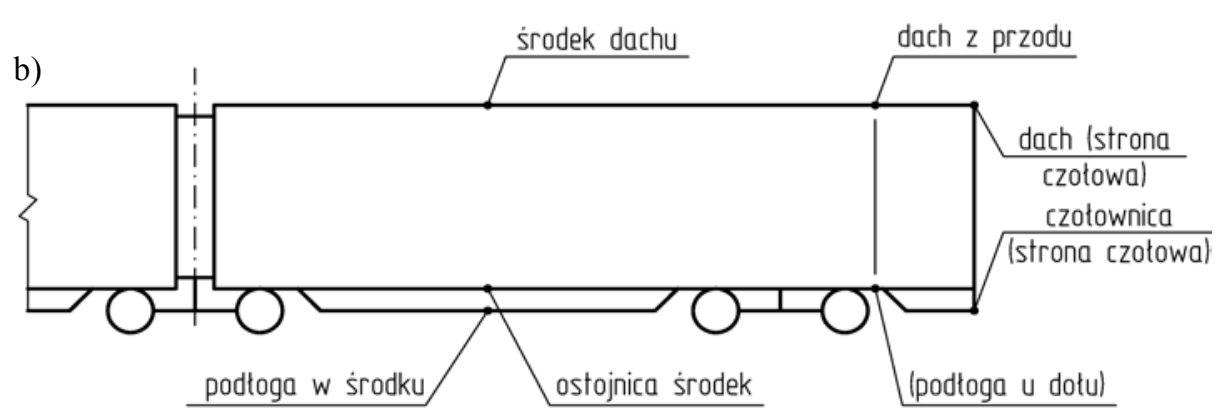

Rys.5. Pojazd tramwajowy, dla którego wyznaczono kinematyczne zapotrzebowanie przestrzeni $\mathrm{w}$ kierunku poprzecznym: aogólny widok pojazdu, brozmieszczenie najbardziej krytycznych punktów na pojeździe. 

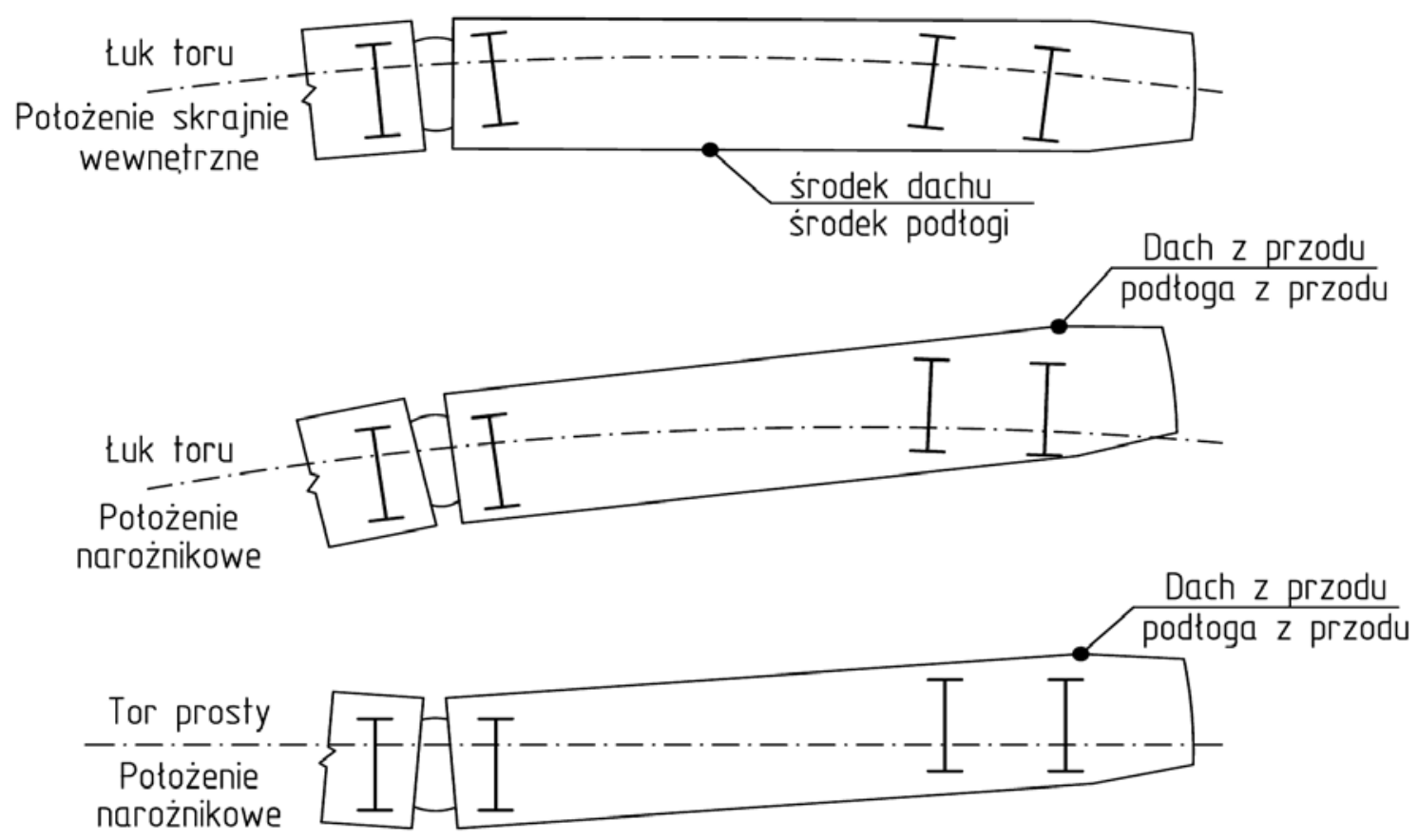

Rys.6. Ustawienia pojazdu w torze oraz punkty pojazdu, dla których wyznaczono kinematyczne zapotrzebowanie przestrzeni

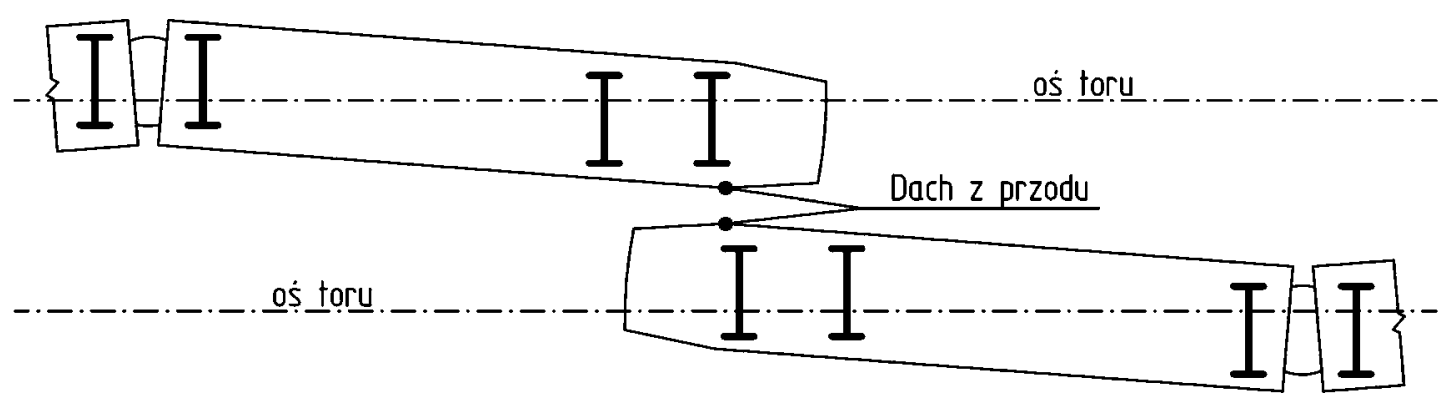

Rys.7. Położenie pojazdów w torze prostym podczas mijania oraz punkty pojazdu, dla których wyznaczono kinematyczne zapotrzebowanie przestrzeni

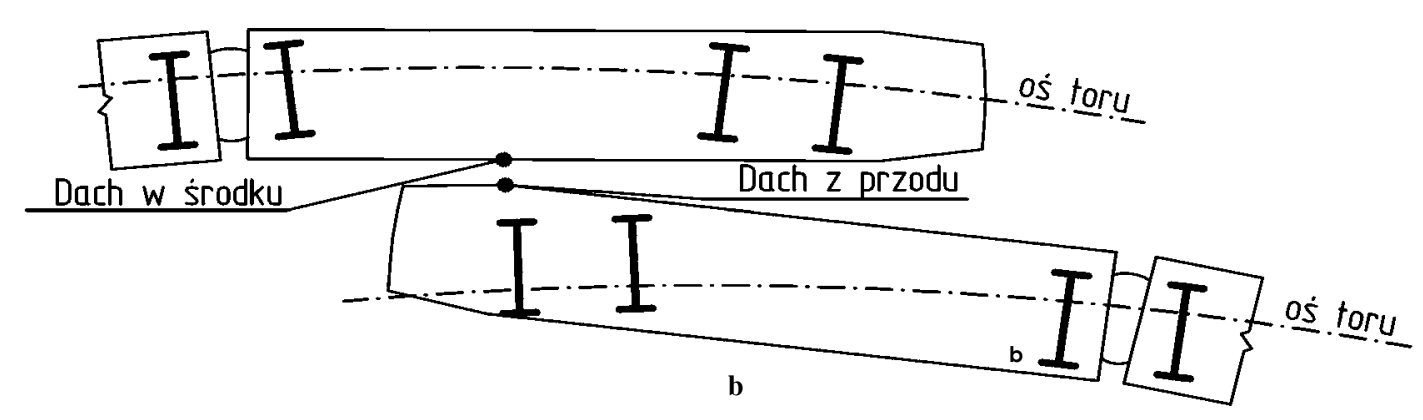

Rys.8. Położenie pojazdów w torze na łuku podczas mijania: a- położenie skrajnie wewnętrzne (tor zewnętrzny), b- położenie narożnikowe (tor wewnętrzny)

Parametry pojazdu tramwajowego przedstawionego na rys.5, wytypowanego do obliczeń kinematycznego zapotrzebowania przestrzeni, są podane w tabeli 1. 
Parametry pojazdu tramwajowego, dla którego wyznaczono kinematyczne zapotrzebo-wanie przestrzeni

Tabela 1

\begin{tabular}{|c|c|c|c|c|}
\hline L.p. & \multicolumn{2}{|c|}{ Opis parametru } & $\begin{array}{l}\text { Oznaczenie para- } \\
\text { metru pojazdu } \\
\text { tramwajowego }\end{array}$ & Wartość parametru \\
\hline 1. & \multicolumn{2}{|c|}{ Całkowita długość pudła pojazdu } & $\mathrm{L}$ & $13400 \mathrm{~mm}$ \\
\hline \multirow[t]{2}{*}{2.} & \multicolumn{2}{|c|}{$\begin{array}{l}\text { Baza pojazdu ( odległość umownych środków } \\
\text { wózków) }\end{array}$} & $\mathrm{a}$ & $10000 \mathrm{~mm}$ \\
\hline & \multicolumn{4}{|c|}{ Położenie badanych punktów pojazdu } \\
\hline 3. & \multicolumn{2}{|c|}{$\begin{array}{l}\text { Dach z przodu, odległość } 1700 \mathrm{~mm} \text { od czopa } \\
\text { skrętu, podłoga z przodu } 1700 \mathrm{~mm} \text { od czopa } \\
\text { skrętu }\end{array}$} & $\mathrm{x}_{1}$ & $6700 \mathrm{~mm}$ \\
\hline 4. & \multicolumn{2}{|c|}{$\begin{array}{l}\text { Dach w środku pomiędzy czopami skrętu, pod- } \\
\text { łoga w środku pomiędzy czopami skrętu }\end{array}$} & $\mathrm{x}_{2}$ & $0 \mathrm{~mm}$ \\
\hline 5. & \multicolumn{2}{|c|}{$\begin{array}{l}\text { Dach, strona czołowa, dolna krawędź podłogi, } \\
\text { ściana czołowa }\end{array}$} & $\mathrm{x}_{3}$ & $8400 \mathrm{~mm}$ \\
\hline \multirow[t]{2}{*}{6.} & \multirow{2}{*}{$\begin{array}{l}\text { Wysokość krawędzi } \\
\text { dachu względem } \\
\text { główki szyny }\end{array}$} & Stan próżny & \multirow[t]{2}{*}{$\mathrm{h}_{\mathrm{d}}$} & $3200 \mathrm{~mm}$ \\
\hline & & Stan ładowny & & $3143 \mathrm{~mm}$ \\
\hline \multirow[t]{2}{*}{7.} & \multirow{2}{*}{$\begin{array}{l}\text { Wysokość górnej } \\
\text { krawędzi podłogi } \\
\text { względem główki } \\
\text { szyny }\end{array}$} & Stan próżny & \multirow[t]{2}{*}{$\mathrm{h}_{\mathrm{p}}$} & $1000 \mathrm{~mm}$ \\
\hline & & Stan ładowny & & $943 \mathrm{~mm}$ \\
\hline 8. & \multicolumn{2}{|l|}{ Szerokość pudła } & $2 b$ & $2650 \mathrm{~mm}$ \\
\hline 9. & \multicolumn{2}{|c|}{ Baza wózka pojazdu tramwajowego } & $\mathrm{p}$ & $2100 \mathrm{~mm}$ \\
\hline \multirow[t]{2}{*}{10} & \multirow{2}{*}{$\begin{array}{l}\text { Usprężynowana masa } \\
\text { pojazdu }\end{array}$} & stan próżny & $\mathrm{m}_{\mathrm{F}, \text { leer }}$ & $9 \mathrm{t}$ \\
\hline & & stan ładowny & $\mathrm{m}_{\mathrm{F}, \text { voll }}$ & $9 \mathrm{t}+12 \mathrm{t}=21 \mathrm{t}$ \\
\hline \multirow[t]{2}{*}{11.} & \multirow[t]{2}{*}{ Sztywność sprężyn } & $\begin{array}{ll}\text { sztywność } & \text { sprężyn } \\
\text { zawieszenia } & \text { pierwsze- } \\
\text { go stopnia } & \\
(\text { na maźnicę) } & \\
\end{array}$ & $\mathrm{C}_{\mathrm{p}}$ & $1500 \mathrm{~N} / \mathrm{mm}$ \\
\hline & & $\begin{array}{l}\text { sztywność sprężyn } \\
\text { zawieszenia drugiego } \\
\text { stopnia } \\
\text { ( na stronę wózka) } \\
\end{array}$ & $\mathrm{C}_{\mathrm{S}}$ & $900 \mathrm{~N} / \mathrm{mm}$ \\
\hline \multirow[t]{2}{*}{12.} & \multirow{2}{*}{$\begin{array}{l}\text { Ugięcie statyczne } \\
\text { sprężyn }\end{array}$} & $\begin{array}{l}\text { sprężyn pierwszego } \\
\text { stopnia } \\
\end{array}$ & $\mathrm{w}_{\mathrm{p}}$ & $13 \mathrm{~mm}$ \\
\hline & & $\begin{array}{l}\text { sprężyn drugiego } \\
\text { stopnia }\end{array}$ & $\mathrm{w}_{\mathrm{S}}$ & $44 \mathrm{~mm}$ \\
\hline \multirow[t]{2}{*}{13.} & \multirow{2}{*}{$\begin{array}{l}\text { Wysokość środka } \\
\text { masy względem głów- } \\
\text { ki szyny }\end{array}$} & W stanie próżnym $^{\text {T) }}$ & \multirow{2}{*}{$\mathrm{h}_{\mathrm{S}}$} & $1150 \mathrm{~mm}$ \\
\hline & & w stanie ładownym $^{\text {I) }}$ & & $1450 \mathrm{~mm}$ \\
\hline 14. & \multicolumn{2}{|c|}{ Powierzchnia parcia wiatru } & $\mathrm{A}_{\mathrm{W}}$ & $36 \mathrm{~m}^{2}$ \\
\hline \multirow[t]{2}{*}{15.} & \multirow{2}{*}{$\begin{array}{l}\text { Wysokość punktu } \\
\text { parcia wiatru }\end{array}$} & W stanie próżnym $^{\text {I) }}$ & $\mathrm{h}_{\mathrm{W}}$ & $1900 \mathrm{~mm}$ \\
\hline & & w stanie ładownym $^{\text {I) }}$ & $\mathrm{h}_{\mathrm{W}}$ & $1843 \mathrm{~mm}$ \\
\hline \multirow[t]{2}{*}{16.} & \multirow{2}{*}{$\begin{array}{l}\text { Odległość pomiędzy } \\
\text { sprężynami w kierun- } \\
\text { ku poprzecznym }\end{array}$} & pierwszego stopnia & $\mathrm{b}_{\mathrm{P}}$ & $1850 \mathrm{~mm}$ \\
\hline & & drugiego stopnia & $\mathrm{b}_{\mathrm{s}}$ & $2000 \mathrm{~mm}$ \\
\hline \multirow[t]{2}{*}{17.} & \multirow{2}{*}{$\begin{array}{l}\text { Wysokość bieguna } \\
\text { pochylania pojazdu z } \\
\text { usprężynowaniem I-go } \\
\text { stopnia }\end{array}$} & w stanie próżnym & $h_{0}$ & $460 \mathrm{~mm}$ \\
\hline & & w stanie ładownym & $\mathrm{n}_{\mathrm{CP}}$ & $447 \mathrm{~mm}$ \\
\hline 18 & Wysokość bieguna & w stanie próżnym & & $800 \mathrm{~mm}$ \\
\hline & $\begin{array}{l}\text { pocnylania pojazau Z } \\
\text { usprężynowaniem II- } \\
\text { go stopnia }\end{array}$ & w stanie ładownym & $\mathrm{n}_{\mathrm{CS}}$ & $743 \mathrm{~mm}$ \\
\hline
\end{tabular}

1) pojazd z petnq obsada pasażerów 
4.2. Przypadki, które uwzględnia się przy określaniu kinematycznego zapotrzebowania przestrzeni

Kinematyczne zapotrzebowanie przestrzeni $\mathrm{w}$ kierunku poprzecznym wyznaczono dla następujących przypadków położeń $\mathrm{w}$ torze $\mathrm{i}$ stanów załadowania pojazdu tramwajowego:

1. Prosty odcinek toru, położenie narożnikowe, pojazd w stanie próżnym

2. Prosty odcinek toru, położenie narożnikowe, pojazd w stanie ładownym

3. Łuk o promieniu $100 \mathrm{~m}$, położenie narożnikowe, pojazd w stanie próżnym

4. Łuk o promieniu $100 \mathrm{~m}$, położenie narożnikowe, pojazd w stanie ładownym

5. Łuk o promieniu $100 \mathrm{~m}$, położenie skrajnie wewnętrzne, pojazd w stanie próżnym

6. Łuk o promieniu100 m, położenie skrajnie wewnętrzne, pojazd w stanie ładownym

7. Mijanie się pojazdów na torach prostych sąsiadujących ze sobą, położenie narożnikowe, pojazdy w stanie ładownym

Wartości kinematycznego zapotrzebowania przestrzeni dla pojazdu tramwajowego z uwzględnieniem połowy szerokości pojazdu i wystawaniem geometrycznym na torze prostym oraz $w$ luku toru, bez uwzględnienia luzów bezpieczeństwa

Tabela 2

\begin{tabular}{|c|c|c|c|c|c|}
\hline \multirow[t]{2}{*}{ L.p. ${ }^{1)}$} & \multirow[t]{2}{*}{ Przypadek } & \multicolumn{4}{|c|}{$\begin{array}{l}\text { Kinematyczne zapotrzebowanie przestrzeni } z \text { uwzględnie- } \\
\text { niem połowy szerokości pojazdu i wystawaniem geome- } \\
\text { trycznym [mm] }\end{array}$} \\
\hline & & \begin{tabular}{|c|} 
Dach z przo- \\
$\mathrm{du}^{2)}$
\end{tabular} & $\begin{array}{l}\text { Podłoga z } \\
\text { przodu }^{2)}\end{array}$ & $\begin{array}{l}\text { Dach w } \\
\text { środku }^{2}\end{array}$ & $\begin{array}{c}\text { Podłoga w } \\
\text { środku }^{2)}\end{array}$ \\
\hline 1. & $\begin{array}{l}\text { Tor prosty, ustawienie narożniko-we, } \\
\text { pojazd bez pasażerów }\end{array}$ & 1422 & 1416 & & \\
\hline 2. & $\begin{array}{l}\text { Tor prosty, ustawienie narożnikowe, } \\
\text { pojazd z kompletem pasażerów }\end{array}$ & 1444 & 1416 & & \\
\hline 3. & $\begin{array}{l}\text { Luk o promieniu } 100 \mathrm{~m} \text {, ustawienie } \\
\text { narożnikowe, pojazd z kompletem } \\
\text { pasażerów }\end{array}$ & 1547 & 1519 & & \\
\hline 4. & $\begin{array}{l}\text { Łuk o promieniu } 100 \mathrm{~m} \text {, ustawienie } \\
\text { narożnikowe, pojazd z kompletem } \\
\text { pasażerów }\end{array}$ & 1566 & 1521 & & \\
\hline 5. & $\begin{array}{l}\text { Luk o promieniu } 100 \mathrm{~m} \text {, } \\
\text { położenie skrajnie wewnętrzne, } \\
\text { pojazd z kompletem pasażerów }\end{array}$ & & & 1567 & 1540 \\
\hline 6. & $\begin{array}{l}\text { Luk o promieniu } 100 \mathrm{~m} \text {, } \\
\text { położenie skrajnie wewnętrzne } \\
\text { pojazd z kompletem pasażerów }\end{array}$ & & - & 1587 & 1542 \\
\hline & Wartość maksymalna & 1566 & 1521 & 1587 & 1542 \\
\hline 7. & $\begin{array}{l}\text { Mijanie się dwóch pojazdów tramwa- } \\
\text { jowych na torze prostym, położenie } \\
\text { narożnikowe, pojazd z kompletem } \\
\text { pasażerów }\end{array}$ & \multicolumn{4}{|c|}{$\begin{array}{l}\text { Wymagana odległość pomiędzy torami odniesiona do dachu } \\
\text { pojazdu } 2583 \mathrm{~mm}\end{array}$} \\
\hline 8. & $\begin{array}{l}\text { Mijanie się dwóch pojazdów tramwa- } \\
\text { jowych na łuku toru o promieniu } \\
100 \mathrm{~m} \text {, położenie narożnikowe, pojazd } \\
\text { z kompletem pasażerów, }\end{array}$ & \multicolumn{4}{|c|}{$\begin{array}{l}\text { Wymagana odległość pomiędzy torami odniesiona do dachu } \\
\text { pojazdu } 3113 \mathrm{~mm}\end{array}$} \\
\hline
\end{tabular}

l) kolejność przypadków odpowiada wymienionym w p.4.2

2) rozpatrywane punkty pojazdu sa przedstawione na rys.5.
8. Mijanie się pojazdów na łukach o promieniu $\mathrm{R}=100$ $\mathrm{m}$, tory sąsiadujące ze sobą, położenie narożnikowe, pojazdy w stanie ładownym.

\subsection{Wartości kinematycznego zapotrzebowania przestrzeni dla przykladowego pojazdu tram- wajowego}

Wartości kinematycznego zapotrzebowania przestrzeni w kierunku poprzecznym bez uwzględnienia luzów bezpieczeństwa wyznaczono w oparciu o wzór (4), przedstawiony w [1], natomiast $\mathrm{z}$ uwzględnieniem luzów bezpieczeństwa odpowiednio wg wzorów (5), (6) i (7), przedstawionych w [1]. Wartości kinematycznego zapotrzebowania przestrzeni dla pojazdu tramwajowego na rys. 5 z jego parametrami konstrukcyjnymi i infrastruktury ( tor tramwajowy wyposażony $\mathrm{w}$ podkłady kolejowe oraz $\mathrm{z}$ nawierzchnia thuczniowa) przedstawionymi w BOStrab [18] z uwzględnieniem połowy szerokości zarysu pojazdu i wystawaniem geometrycznym na torze prostym oraz w łuku toru, bez uwzględnienia luzów bezpieczeństwa są przedstawione w tabeli 2 . 
Wartości kinematycznego zapotrzebowania przestrzeni dla pojazdu tramwajowego przedstawionego na rys.5 bez uwzględnienia połowy szerokości zarysu pojazdu i wystawaniem geometrycznym na torze prostym oraz w łuku toru, bez uwzględnienia luzów bezpieczeństwa są przedstawione w tabeli 3 .

Wartości kinematycznego zapotrzebowania przestrzeni dla pojazdu tramwajowego przedstawionego na rys. $5 \mathrm{z}$ uwzględnieniem połowy szerokości zarysu pojazdu i wystawaniem geometrycznym na torze prostym oraz w łuku toru, z uwzględnieniem luzów bezpieczeństwa są przedstawione w tabeli 4 .

Wartości kinematycznego zapotrzebowania przestrzeni dla pojazdu tramwajowego przedstawionego na rys.5 bez uwzględnienia połowy szerokości zarysu pojazdu i wystawania geometrycznego na torze prostym oraz $\mathrm{w}$ łuku toru, $\mathrm{z}$ uwzględnieniem luzów bezpieczeństwa są przedstawione w tabeli 5 .
$\mathrm{Z}$ porównania wyników przedstawionych $\mathrm{w}$ tabelach $2 \div 5$ wynika, że obliczenia kinematycznego zapotrzebowania przestrzeni w kierunku poprzecznym przeprowadzone w oparciu o dokładną znajomość pojazdu i infrastruktury ( tabele 2 i 3) daja zdecydowane korzyści przestrzenne niż $\mathrm{w}$ przypadku analogicznych obliczeń z uwzględnieniem luzów bezpieczeństwa ( tabele 4 i 5). W przypadku braku wystarczającej wiedzy na temat pojazdu i infrastruktury rezultatem obliczeń jest „przewymiarowana przestrzeń kinematycznego zapotrzebowania" pojazdu tramwajowego, która prowadzi do większego bezpieczeństwa eksploatacyjnego, ale może utrudniać spełnianie podstawowych funkcji pojazdu do jakich można zaliczyć chociażby wsiadanie $i$ wysiadanie $z$ pojazdu. Jest to bardzo istotny parametr oceny pojazdu szynowego, decydujący również o jego przelotowości i czasie postoju na przystankach. Na rys.9 przedstawiono sytuacje przy wsiadaniu pasażerów do tramwajów z obniżoną podłogą ( niem. „Niederflurstraßenbahnfahrzeuge”) będących własnością francuskich przedsiębiorstw przewozowych w Nantes oraz w Grenoble.

Wartości kinematycznego zapotrzebowania przestrzeni dla pojazdu tramwajowego bez uwzględnienia połowy szerokości pojazdu i wystawaniem geometrycznym na torze prostym i w luku, bez uwzględnienia luzów bezpieczeństwa

Tabela 3

\begin{tabular}{|c|c|c|c|c|c|}
\hline \multirow[t]{2}{*}{ L.p. ${ }^{1)}$} & \multirow[t]{2}{*}{ Przypadek } & \multicolumn{4}{|c|}{$\begin{array}{c}\text { Kinematyczne zapotrzebowanie przestrzeni z uwzględnie- } \\
\text { niem połowy szerokości pojazdu i wystawaniem geome- } \\
\text { trycznym [mm] }\end{array}$} \\
\hline & & $\begin{array}{l}\text { Dach z przo- } \\
\mathbf{d u}^{2)}\end{array}$ & $\begin{array}{l}\text { Podłoga } z \\
\text { przodu }^{2}\end{array}$ & $\begin{array}{l}\text { Dach w } \\
\text { środku') }\end{array}$ & $\begin{array}{c}\text { Podłoga w } \\
\text { środku' }\end{array}$ \\
\hline 1. & $\begin{array}{l}\text { Tor prosty, ustawienie narożniko-we, } \\
\text { pojazd bez pasażerów }\end{array}$ & 117 & 91 & & \\
\hline 2. & $\begin{array}{l}\text { Tor prosty, ustawienie narożnikowe, } \\
\text { pojazd z kompletem pasażerów }\end{array}$ & 119 & 91 & & \\
\hline 3. & $\begin{array}{l}\text { Łuk o promieniu } 100 \mathrm{~m} \text {, ustawienie } \\
\text { narożnikowe, pojazd z kompletem } \\
\text { pasażerów }\end{array}$ & 131 & 103 & & \\
\hline 4. & $\begin{array}{l}\text { Łuk o promieniu } 100 \mathrm{~m} \text {, ustawienie } \\
\text { narożnikowe, pojazd z kompletem } \\
\text { pasażerów }\end{array}$ & 150 & 105 & & \\
\hline 5. & $\begin{array}{l}\text { Łuk o promieniu } 100 \mathrm{~m}, \\
\text { położenie skrajnie wewnętrzne, } \\
\text { pojazd z kompletem pasażerów }\end{array}$ & & & 111 & 84 \\
\hline 6. & $\begin{array}{l}\text { Łuk o promieniu } 100 \mathrm{~m} \text {, } \\
\text { położenie skrajnie wewnętrzne } \\
\text { pojazd z kompletem pasażerów }\end{array}$ & & - & 131 & 86 \\
\hline & Wartość maksymalna & 150 & 105 & 131 & 86 \\
\hline 7. & $\begin{array}{l}\text { Mijanie się dwóch pojazdów tramwa- } \\
\text { jowych na torze prostym, położenie } \\
\text { narożnikowe, pojazd z kompletem } \\
\text { pasażerów }\end{array}$ & \multicolumn{4}{|c|}{$\begin{array}{l}\text { Wymagana odległość pomiędzy torami odniesiona do dachu } \\
\text { pojazdu } 203 \mathrm{~mm}\end{array}$} \\
\hline 8. & $\begin{array}{l}\text { Mijanie się dwóch pojazdów tramwa- } \\
\text { jowych na łuku toru o promieniu } \\
100 \mathrm{~m} \text {, położenie narożnikowe, pojazd } \\
\text { z kompletem pasażerów, }\end{array}$ & \multicolumn{4}{|c|}{$\begin{array}{l}\text { Wymagana odległość pomiędzy torami odniesiona do dachu } \\
\text { pojazdu } 241 \mathrm{~mm}\end{array}$} \\
\hline
\end{tabular}

I) kolejność przypadków odpowiada wymienionym w p.4.2

2) rozpatrywane punkty pojazdu sa przedstawione na rys.5 
Wartości kinematycznego zapotrzebowania przestrzeni dla pojazdu tramwajowego $z$ uwzględnieniem połowy szerokości pojazdu i wystawaniem geometrycznym na torze prostym i w luku $z$ uwzględnieniem luzów bezpieczeństwa

Tabela 4

\begin{tabular}{|c|c|c|c|c|c|}
\hline \multirow[t]{2}{*}{ L.p. } & \multirow[t]{2}{*}{ Przypadek } & \multicolumn{4}{|c|}{$\begin{array}{c}\text { Kinematyczne zapotrzebowanie przestrzeni z uwzględnie- } \\
\text { niem polowy szerokości pojazdu i wystawaniem geome- } \\
\text { trycznym [mm] }\end{array}$} \\
\hline & & $\begin{array}{c}\text { Dach z przo- } \\
\mathbf{d u}^{2)}\end{array}$ & $\begin{array}{l}\text { Podłoga } z \\
\text { przodu }^{2)}\end{array}$ & $\begin{array}{l}\text { Dach w } \\
\text { środku }\end{array}$ & $\begin{array}{l}\text { Podłoga } w \\
\text { środku }\end{array}$ \\
\hline 1. & $\begin{array}{l}\text { Tor prosty, ustawienie narożniko-we, } \\
\text { pojazd bez pasażerów }\end{array}$ & \multirow[b]{2}{*}{1525} & \multirow[b]{2}{*}{1441} & & \\
\hline 2. & $\begin{array}{l}\text { Tor prosty, ustawienie narożniko-we, } \\
\text { pojazd z kompletem pasaże-rów }\end{array}$ & & & & \\
\hline 3. & $\begin{array}{l}\text { Łuk o promieniu } 100 \mathrm{~m} \text {,ustawienie } \\
\text { narożnikowe, pojazd z kompletem } \\
\text { pasażerów }\end{array}$ & \multirow[t]{2}{*}{1625} & \multirow[t]{2}{*}{1545} & & \\
\hline 4. & $\begin{array}{l}\text { Luk o promieniu } 100 \mathrm{~m} \text {,ustawienie } \\
\text { narożnikowe, pojazd z kompletem } \\
\text { pasażerów }\end{array}$ & & & & \\
\hline 5. & $\begin{array}{l}\text { Łuk o promieniu } 100 \mathrm{~m} \text {, położenie } \\
\text { skrajnie wewnętrzne, pojazd z kom- } \\
\text { pletem pasażerów }\end{array}$ & & & & \\
\hline \multirow[t]{2}{*}{6.} & $\begin{array}{l}\text { Luk o promieniu } 100 \mathrm{~m} \text {, położenie } \\
\text { skrajnie wewnętrzne pojazd z kom- } \\
\text { pletem pasażerów }\end{array}$ & & & 1656 & 1578 \\
\hline & Wartość maksymalna & 1625 & 1545 & 1656 & 1578 \\
\hline 7. & $\begin{array}{l}\text { Mijanie się dwóch pojazdów tramwa- } \\
\text { jowych na torze prostym, położenie } \\
\text { narożnikowe, pojazd z kompletem } \\
\text { pasażerów }\end{array}$ & \multicolumn{4}{|c|}{$\begin{array}{l}\text { Wymagana odległość pomiędzy torami odniesiona do dachu } \\
\text { pojazdu } 3022 \mathrm{~mm}\end{array}$} \\
\hline 8. & $\begin{array}{l}\text { Mijanie się dwóch pojazdów tramwa- } \\
\text { jowych na łuku toru o promieniu } \\
\text { 100m, położenie narożnikowe, pojazd } \\
\text { z kompletem pasażerów, }\end{array}$ & \multicolumn{4}{|c|}{$\begin{array}{l}\text { Wymagana odległość pomiędzy torami odniesiona do dachu } \\
\text { pojazdu } 3245 \mathrm{~mm}\end{array}$} \\
\hline
\end{tabular}

l) kolejność przypadków odpowiada wymienionym w p.4.2

2) rozpatrywane punkty pojazdu sa przedstawione na rys. 5

Wartości kinematycznego zapotrzebowania przestrzeni dla pojazdu tramwajowego bez uwzględnienia połowy szerokości pojazdu i z wystawaniem geometrycznym na torze prostym i w luku z uwzględnieniem luzów bezpieczeństwa

Tabela 5

\begin{tabular}{|c|c|c|c|c|c|}
\hline \multirow[t]{2}{*}{ L.p. } & \multirow[t]{2}{*}{ Przypadek } & \multicolumn{4}{|c|}{$\begin{array}{l}\text { Kinematyczne zapotrzebowanie przestrzeni } z \text { uwzględnie- } \\
\text { niem połowy szerokości pojazdu i wystawaniem geome- } \\
\text { trycznym [mm] }\end{array}$} \\
\hline & & $\begin{array}{c}\text { Dach z przo- } \\
\mathbf{d u}^{2)}\end{array}$ & $\begin{array}{l}\text { Podłoga } z \\
\text { przodu }^{2)}\end{array}$ & $\begin{array}{c}\text { Dach w środ- } \\
\mathbf{k u}^{2)}\end{array}$ & $\begin{array}{l}\text { Podłoga } w \\
\text { środku' }\end{array}$ \\
\hline 1 . & $\begin{array}{l}\text { Tor prosty, ustawienie narożnikowe, } \\
\text { pojazd bez pasażerów }\end{array}$ & \multirow[t]{2}{*}{200} & \multirow[t]{2}{*}{116} & & \\
\hline 2. & $\begin{array}{l}\text { Tor prosty, ustawienie narożnikowe, } \\
\text { pojazd z kompletem pasażerów }\end{array}$ & & & & \\
\hline 3. & $\begin{array}{l}\text { Łuk o promieniu } 100 \mathrm{~m} \text {, ustawienie } \\
\text { narożnikowe, pojazd z kompletem } \\
\text { pasażerów }\end{array}$ & \multirow[t]{2}{*}{209} & \multirow[t]{2}{*}{129} & & \\
\hline 4. & $\begin{array}{l}\text { Łuk o promieniu } 100 \mathrm{~m} \text {, ustawienie } \\
\text { narożnikowe, pojazd z kompletem } \\
\text { pasażerów }\end{array}$ & & & & \\
\hline
\end{tabular}


c.d. Tabeli 5

\begin{tabular}{|c|c|c|c|c|c|}
\hline 5. & $\begin{array}{l}\text { Łuk o promieniu } 100 \mathrm{~m} \text {, } \\
\text { położenie skrajnie wewnętrzne, } \\
\text { pojazd z kompletem pasażerów }\end{array}$ & & & \multirow{2}{*}{200} & \multirow{2}{*}{122} \\
\hline \multirow[t]{2}{*}{6.} & $\begin{array}{l}\text { Łuk o promieniu } 100 \mathrm{~m} \text {, } \\
\text { położenie skrajnie wewnętrzne } \\
\text { pojazd z kompletem pasażerów }\end{array}$ & & & & \\
\hline & Wartość maksymalna & 209 & 129 & 200 & 122 \\
\hline 7. & $\begin{array}{l}\text { Mijanie się dwóch pojazdów } \\
\text { tramwajowych na torze prostym, } \\
\text { położenie narożnikowe, pojazd z } \\
\text { kompletem pasażerów }\end{array}$ & \multicolumn{4}{|c|}{$\begin{array}{l}\text { Wymagana odległość pomiędzy torami odniesiona do dachu } \\
\text { pojazdu } 372 \mathrm{~mm}\end{array}$} \\
\hline 8. & $\begin{array}{l}\text { Mijanie się dwóch pojazdów } \\
\text { tramwajowych na łuku toru o } \\
\text { promieniu } 100 \mathrm{~m} \text {, położenie } \\
\text { narożnikowe, pojazd z kompletem } \\
\text { pasażerów, }\end{array}$ & \multicolumn{4}{|c|}{$\begin{array}{l}\text { Wymagana odległość pomiędzy torami odniesiona do dachı } \\
\text { pojazdu } 373 \mathrm{~mm}\end{array}$} \\
\hline
\end{tabular}

l) kolejność przypadków odpowiada wymienionym w p.4.2

2) rozpatrywane punkty pojazdu sq przedstawione na rys. 5
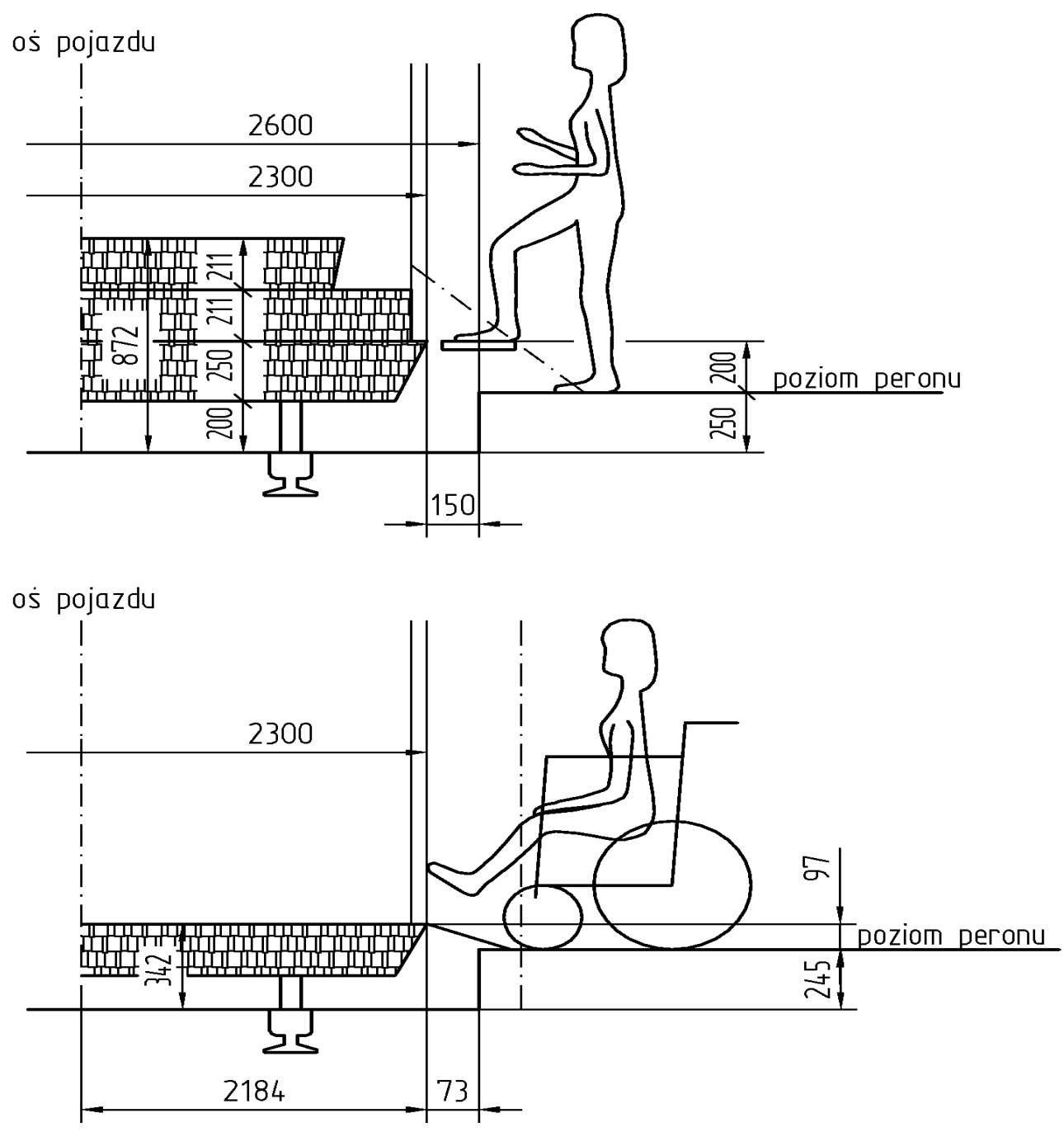

Rys.9. Warunki dla pasażerów przy wsiadaniu do tramwajów niskopodłogowych: a) w Nantes b) w Grenoble 
Ta komfortowa sytuacja przy wsiadaniu ( niem. „Einstiegskomfort” lub „komfortable Einstiegssituation”), wypracowana dużym kosztem przedsięwzięć technicznych może się znacznie pogorszyć w przypadku tramwajów, których zapotrzebowanie przestrzeni jest wyliczone w oparciu o luz bezpieczeństwa. Pojazd o większym kinematycznym zapotrzebowaniu przestrzeni posiada większą odległość od peronu, co utrudnia wsiadanie $\mathrm{i}$ wysiadanie pasażerom $\mathrm{i}$ aby to ułatwić środki techniczne muszą posiadać większe wymiary geometryczne ( dłuższe wysuwane podesty). $\mathrm{Na}$ tym przykładzie widoczne są zalety wyznaczania kinematycznego zapotrzebowania przestrzeni w oparciu o metodę bez uwzględniania luzów bezpieczeństwa.

\section{Omówienie i wnioski}

$\mathrm{Z}$ analizy przedstawionej dla kinematycznego zapotrzebowania przestrzeni dla pojazdu tramwajowego bez i z uwzględnieniem luzów bezpieczeństwa można zauważyć, że zastosowana metoda wyznaczania daje istotne korzyści przestrzenne dla pojazdu i infrastruktury $\mathrm{w}$ pierwszym przypadku tzn. bez uwzględnienia luzów bezpieczeństwa. Metoda bez uwzględnienia luzów bezpieczeństwa wymaga szczegółowej wiedzy na temat budowy pojazdu, jego tolerancji oraz infrastruktury, na której ten pojazd jest eksploatowany. Może się okazać, że ten sam pojazd w innych warunkach oferowanych przez infrastrukturę innego przedsiębiorstwa przewozowego może wykazywać mniejsze lub większe kinematyczne zapotrzebowanie przestrzeni. Wyznaczanie kinematycznego zapotrzebowania przestrzeni dla drugiego przypadku tzn. uwzględnieniem luzów bezpieczeństwa jest obliczane przy założeniu, że stosowanie pojazdu w eksploatacji komercyjnej jest ,a'priori” obarczone ryzykiem, które ma za zadanie zrekompensować luzy bezpieczeństwa. Jak wykazuje porównanie obliczeń kinematycznego zapotrzebowania przestrzeni wg tabeli odpowiednio 2 i 4 oraz 3 i 5 metoda bez uwzględnienia luzów bezpieczeństwa wykazuje $59 \mathrm{~mm}$ zysk przestrzenny ( po każdej stronie w kierunku poprzecznym), gwarantując jednocześnie bezpieczną eksploatację pojazdu tramwajowego. Zaletę te można wykorzystać konstruując pojazd tramwajowy o większej szerokości, zapewniając tym samym większy komfort dla podróżnych.

W przypadku poszukiwania optymalnych konstrukcji o wysokich wskaźnikach przewozowych i o budowie wielkogabarytowej należy liczyć się z tym, że dokładne obliczenie kinematycznego zapotrzebowania przestrzeni jest możliwe pod warunkiem dokładnego poznania budowy pojazdu i infrastruktury. Kinematyczne zapotrzebowanie przestrzeni jest pojęciem, które określa rzeczywistą przestrzeń, jaką zajmuje pojazd w określonych warunkach eksploatacyjnych. Może ono być zwiększone lub zmniejszone w zależności od wymagań infrastruktury ( przeglądy okresowe, ich dokładność oraz częstotliwość) jak również konstrukcji samego pojazdu ( częstotliwości napraw). Wytyczne zapotrzebowania przestrzeni można zmniejszyć dla tego samego pojazdu poprzez dokonywanie zabiegów konstrukcyjnych, ograniczające tolerancje wykonawcze poszczególnych podzespołów, jakimi są układ biegowy oraz pudło. O celowości tego zabiegu decydują nie tylko możliwości technologiczne wytwórni, ale również ekonomiczne jakie powoduje zawężenie odchyłek wykonawczych.

Istotnym parametrem ekonomicznokonstrukcyjnym, świadczącym o konstrukcji jest parametr kosztowy wskazujący na cenę $1 \mathrm{~m}^{2}$ powierzchni użytkowej tramwaju ( cena pojazdu podzielona przez powierzchnię użytkową tramwaju). Przedstawiona metoda wyznaczania kinematycznego zapotrzebowania przestrzeni ma walory rozwojowe, znosząc dotychczasowy podział kompetencji między służby budowlane i konstruktora pojazdu. Przyczynia się ona do poznania jakościowego i ilościowego udziału poszczególnych czynników, wpływających na przemieszczenia pojazdu i bardziej mobilizuje producenta i przedsiębiorstwo przewozowe do współpracy nad optymalnym rozwiązaniem wspólnego problemu jakim jest bezpieczna eksploatacja pojazdu tramwajowego, dopasowanego do wymagań rynkowych ( optymalna ilość miejsc stojących oraz siedzących).

Metoda ta może być uznana przez polskie przedsiębiorstwa komunikacji miejskiej jako jedna $\mathrm{z}$ bazowych do wyznaczania zarysu pojazdu i jego kinematycznego zapotrzebowania przestrzeni, przy założeniu dopasowania jej do warunków krajowych miejskich przedsiębiorstw przewozowych. Nakłada ona na konstruktora pojazdu obowiązek dokładnego poznania infrastruktury, po której będzie poruszał się pojazd. O ile w przypadku infrastruktury kolejowej jest to trudne $\mathrm{z}$ uwagi na jej zasiegg, to w przypadku miejskiego przedsiębiorstwa komunikacyjnego nie powinno przedstawiać większych trudności.

\section{Literatura}

[1] Sobaś M.: Luzy bezpieczeństwa między skrajniq kinematyczna $i$ skrajnia budowli dla pojazdów tramwajowych (1). Pojazdy Szynowe Nr 1/2008. 